an indomitable optimism, an infectious love of friendship, and a thorough commitment to the fellowship-her legacy includes a standard of excellence as a Fellow which will be hard to match by the generations of Fellows who will follow in her wake. She was the epitome of what can hope for in the international participation in the fellowship.

With a Ph.D. in political science from the Australian National University, an MA in political science from the University of Canterbury, New Zealand, and a Diploma of Journalism from Wellington Polytechnic, New Zealand, Sarah Miskin entered the APSA Congressional Fellowship as the Acting Executive Adviser to the Secretary of the Department of Parliamentary Services, Parliament House, Canberra, Australia. She was the author of a score of publications dealing with the Australian parliamentary process and had been the book review editor of the Australian Political Studies Association Journal, the Australian Journal of Political Science, since February 2006. In her recommendation of Sarah for the Fellowship, the Australian Parliamentary Librarian noted that "she has displayed an outstanding ability to analyse, think creatively about a range of issues and work with others on assessing the future directions of our clients and of the Library's services. The Congressional Fellowship would provide a very timely opportunity for her to take forward her work on delivering information and analysis services to Senators and Members [of the U.S. Congress]." Although the expectation was not to be fulfilled, she will be remembered in the months and years ahead by those Congressional Fellows and congressional staff who were fortunate enough to begin to know her in the regrettably brief period of her time with us.

\section{PHILIP J. SCHLESSINGER}

Dr. Philip J. Schlessinger died at age 96 on September 22, 2010. He had taught political science at Los Angeles City College (LACC) for more than 60 years.

Originally from Minneapolis, he received his bachelor's and master's degrees at the University of Minnesota, where he and Hubert Humphrey were teaching assistants together. Schlessinger received his doctorate in public administration from the University of Southern California in 1943. He started teaching at LACC in 1947 and also taught courses over the years at Ful- lerton Community College, California State College in Los Angeles, and California State College at Northridge. He formally retired from LACC in 1986 but continued teaching courses there into his gos.

His scholarship included authoring multiple editions of Elements of California Government. He motivated students to participate in government, taking students on field trips to observe the California legislature and inspiring many of his students to seek careers in public office.

Dr. Schlessinger was a political activist. He served on the Democratic Party's State Central Committee in the 1950 and ran for the California state assembly several times, losing by only 190 votes in 1958 . His most important success as a lobbyist on behalf of his school was getting the Los Angeles Community College District separated from the Los Angeles Unified School Board. He served on the University of California Regents advisory committee. He was appointed in 1987 as a public member of the California Psychology Examining Board. He served as the secretary to the board and as the chair of its Legislation Committee, acting as liaison between the board and the legislature in successful efforts to change the board's name to the Board of Psychology and establish mandatory continuing education for psychologists.

He was married to his wife Phyllis for 60 years before she predeceased him. They enjoyed cruising around the world several times. My cousin proudly showed me Dr. Schlessinger's architecturally significant house in the Los Feliz area of Los Angeles, a house that was designed for the couple in 1952 by Viennese-born architect Rudolf Schindler.

Philip Schlessinger was recognized in 2001 by the Los Angeles Community College with their Outstanding Humanitarian Award. In accepting that award, he explained that LACC was his dream college, because "it discriminates against no one, puts up no forbidding financial barriers, and sets up its operations for the many students who must work to attend college."

Herbert F. Weisberg The Ohio State University

\section{FRANK TACHAU}

Frank Tachau, one of the leading scholars of Middle Eastern politics, died on July 23, 2010, at the age of 80 in Sykesville, Mary- land, after battling with multiple myeloma for two years. Born in Braunschweig, Germany, Professor Tachau moved with his family to Chicago at the age of seven in 1936. He studied at the University of Chicago, earning a bachelor's and a master's degree in political science. His MA thesis on the diplomacy of the Turkish Straits between 1936 and 1946 led to his remarkable Ph.D. dissertation, which offered one of the first scholarly accounts of Turkish nationalism in 1958. What distinguished Professor Tachau's analyses from others studying the Middle East was his extensive ethnographic work in the region. His unique language skills allowed him to learn modern Turkish very quickly in 1956 and opened the door for him to master historical Ottoman Turkish as well. During his multiple visits to the region, Professor Tachau studied the history of the Ottoman Empire and also noted the emerging institutions of the new Turkish republic. His extensive stays in the region equipped him with unique insights into the views of the country's political elite and the mechanisms of its fledgling democracy.

Professor Tachau started his academic career at Purdue University-Fort Wayne (Indiana), before moving on to Rutgers University. He joined the University of Illinois at Chicago Circle, now the University of Illinois at Chicago (UIC), in 1968 and spent the remainder of his professional life there. He was an active participant in the drastic transformation of UIC from a littleknown state university to a university of international stature. The ensuing rapid growth of the political science department faced challenges. He provided significant leadership along the way, stepping in when needed to chair the department on two occasions for a total of eight years. He and his wife Paula tirelessly provided intellectual and social leadership by opening their home on countless occasions for departmental events. His thoughtful and piercingly effective leadership helped to smooth out the rough edges in a demanding and often taxing institutionalization process.

Professor Tachau's scholarly interest covered a broad range. He was truly an interdisciplinary scholar before the term became fashionable. One of the many things that set him apart from others was his willingness to write books for an unconventional audience and his ability to make his work relevant to broader audiences. He did not shy away, for instance, from contributing to a school book series 